\title{
India - Measures Affecting the Automotive Sector*
}

BY

KYLE BAGWELL

Columbia University

AND

ALAN O. SYKES

University of Chicago

\section{Introduction}

This study addresses the disputes brought to the World Trade Organization (WTO) by the European Communities and the United States concerning certain Indian measures affecting the importation of automobiles and components in the form of "completely knocked down" (CKD) and "semi-knocked down" (SKD) kits. The measures in question originated during a time when India employed extensive import licensing requirements, ostensibly for balance of payments purposes. India's broad licensing regime was challenged in 1997 by the European Communities and the United States, resulting in a settlement with the European Communities and a ruling in favor of the United States pursuant to which India agreed to abolish its import licensing system. Some restrictions in the automotive sector remained, however, which became the subject of this proceeding.

The automotive restrictions resulted from a law known as Public Notice 60 (PN60), enacted in 1997, which provided that companies desiring to obtain import licenses for CKD or SKD kits must enter a contract with the government known as a "Memorandum of Understanding" (MOU). These MOUs, among other things, required companies to achieve stated local content percentages ("indigenization requirements") in their manufacturing operations, and to ensure that the value of their

* We wish to thank Alberto Martin for valuable assistance, and to thank the other reporters and conference participants of the American Law Institute for many valuable ideas and suggestions. 
exports was equal to the value of their imports ("trade balancing requirements"). The contractual commitments to the government through the MOUs remained binding and enforceable even after the import licensing regime that had given rise to them was abolished. The European Communities and the United States claimed that the indigenization requirements and the trade balancing requirements constituted violations of Articles III and XI of GATT 1994 and Article 2 of TRIMs.

The proceedings were consolidated before a single dispute panel, which ruled in favor of the European Communities and the United States with respect to both measures. ${ }^{1}$ India indicated that it would appeal, but later withdrew its appeal and thus the Appellate Body did not address the substance of the dispute. ${ }^{2}$ In a communication dated November 6, 2002, India informed the Dispute Settlement Body that it had issued new Public Notices withdrawing the indigenization and trade balancing requirements contained in Public Notice 60, and by implication suggesting that any such requirements in surviving MOUs would be deprived of effect.

The dispute is an unremarkable one and of limited significance from a legal standpoint. The indigenization requirements and trade balancing requirements are clear violations of GATT 1994 and TRIMs in the absence of a valid defense. India's purported justification for them - a balance of payments justification under Article XVIII of GATT 1994 - had been found insufficient in the earlier proceeding regarding its import licensing system. The case does touch on some broader legal issues of systemic importance: the role of res judicata in WTO law, the question of what constitutes governmental action sufficient to constitute a "requirement" or "measure," and the boundary between border measures covered by Article XI and domestic measures covered by Article III. But the case breaks little new ground on any of these points.

From an economic perspective, the issues raised by the case are also quite straightforward. Local content requirements such as the "indigenization" requirement, and measures such as the trade balancing requirement, disadvantage imports and the companies that use them. They can be understood as protectionist measures that benefit the domestic producers of inputs. Such measures may harm foreign manufacturers and input suppliers, and it is thus appropriate that WTO law should condemn them.

${ }^{1}$ Report of the Panel in India - Measures Affecting the Automotive Sector, WT/DS146/R, WT/DS175/R, adopted April 5, 2002 (hereafter Panel Rep.).

2 Report of the Appellate Body in India - Measures Affecting the Automotive Sector, WT/DS146/R, WT/DS175/R, adopted April 5, 2002. 
We proceed in the conventional fashion, laying out the legal issues and arguments in Section 2. Section 3 offers a critical analysis of the case from a law and economics perspective.

\section{Factual and Legal Issues}

\subsection{The history and nature of the measures at issue}

For many years, India applied import restrictions that it justified on balance of payments grounds. The restrictions were administered through an import licensing system. In 1997, the European Communities requested consultations with respect to all import restrictions maintained by India, including those on the products at issue in the automotive dispute. India and the European Communities reached a settlement later that year, a "mutually agreed solution" in WTO parlance, which called for all of the restrictions to be eliminated by March 31, 2003.

Also in 1997, the US requested consultations with India regarding quantitative restrictions applied by India for balance of payments reasons on 2,714 agricultural and industrial product lines. That dispute proceeded to a panel, which ruled that the restrictions violated Article XI(1) of GATT 1994 and were not justified by Article XVIII:B of GATT 1994 (pertaining to balance of payments measures by developing countries). ${ }^{3}$ The Appellate Body upheld these findings. ${ }^{4}$ The United States and India subsequently agreed that India would comply with the recommendations and rulings of the DSB no later than April 1, 2001, by which time India would eliminate the system of non-automatic licenses for imports.

In 2000, when the panel in the automotive dispute was requested by the United States and the European Communities, India still applied discretionary import licensing to 715 tariff line items including cars imported in the form of CKD and SKD kits. Pursuant to the agreement reached in the earlier proceedings, however, India altogether abolished its licensing scheme on April 1, 2001.

The end of the import licensing system did not end European and American concerns about the automotive sector, however, because of PN60 and the MOUs that resulted from it. PN60 required any passenger

${ }^{3}$ Panel Report on India - Quantitative Restrictions on Imports of Agricultural, Textile and Industrial Products, (hereinafter "India - Quantitative Restrictions"), WT/DS/90/R, adopted September 22, 1999.

${ }^{4}$ Report of the Appellate Body in India - Quantitative Restrictions, WT/DS90/AB/R, adopted on September 22, 1999. 
car manufacturer wishing to obtain a license to import CKD or SKD kits to covenant, through an MOU, to:

(i) "Establishment of actual production facilities for manufacture of cars, and not for mere assembly.

(ii) A minimum of foreign equity of US $\$ 50$ million to be brought in by the foreign partner within the first three years of the start of operations, if the firm is a joint venture that involves majority foreign equity ownership.

(iii) Indigenization (i.e. local content) of components up to a minimum level of 50\% in the third year or earlier from the date of first import consignment of CKD/SKD kits/components, and 70\% in the fifth year or earlier.

(iv) broad trade balancing of foreign exchange over the entire period of the MOU, in terms of balancing between the actual CIF value of imports of CKD/SKD kits/components and the FOB value of exports of cars and auto components over that period..."

The third and fourth of these requirements became the subject of the automotive dispute.

Much of India's defense in the case rested on the proposition that the matter had already been resolved through the challenges to India's broad import licensing regime, or that it was otherwise mooted by the abolition of the licensing regime in 2001. But the European Communities and the United States argued that even if the import licensing regime that had been used to extract the commitments in the MOUs had ended, PN60 remained on the books and the MOUs that had been negotiated under it remained binding on the companies that had signed them.

\subsection{The Panel decision}

\subsubsection{Relevance of prior proceedings on India - Quantitative} Restrictions

Much of the panel decision relates to India's claims that the claims brought by the European Communities and the United States had already been resolved or were moot. The panel disagreed.

India argued first that the measures in question were no longer in existence due to developments subsequent to the initiation of the dispute. The panel responded by noting that the indigenization and

\footnotetext{
5 Panel Rep. 2.5.
} 
trade balancing requirements, as embodied in the MOUs, remained in effect after the licensing system was abolished. ${ }^{6}$

India also made a rather novel res judicata argument. Ordinarily, a party to litigation invoking the concept of res judicata does so to avoid relitigating an issue that it prevailed on in a prior proceeding. Here, by contrast, India invoked res judicata with respect to the issues that it had lost in the India - Quantitative Restrictions dispute. India's theory was that the United States and the European Communities could not seek a new ruling on the legality of measures that a previous dispute had addressed. The panel seemed to accept that in principle it was improper to relitigate the same issues, but concluded that the measures at issue in the automotive sector had not been before the prior dispute panel. The prior dispute had concerned the legality of the broad import licensing regime, but had not considered the indigenization and trade balancing requirements in the MOUs. ${ }^{7}$

The panel gave a similar response to India's argument that the measures in question could not be adjudicated because they were covered by the "mutually agreed solution" reached with the European Communities after its prior complaint. That agreement contained a promise by the European Communities to refrain from bringing further proceedings relating to the challenged measures, in exchange for India's promise to remove them over time. The panel accepted the proposition that Europe would be bound by its promise, but found once again that it did not encompass the specific measures at issue in the automotive sector. $^{8}$

\subsubsection{Analysis of challenged measures under GATT 1994 and TRIMs}

Regarding the order of analysis, the panel saw little difference in the "specificity" of GATT 1994 and TRIMs with respect to the challenged measures. Accordingly, it decided to address the claims in the order that they were argued by the parties.

2.2.2.1 The indigenization requirement As noted, the indigenization requirement committed the companies signing MOUs to procure

\footnotetext{
6 Panel Rep. 7.28.

7 Panel Rep. 7.103.

8 Panel Rep. 7.132-734.
} 
50-70 percent of their automobile parts and components from local sources, and was a classic local content requirement in WTO parlance. Both the European Communities and the United States claimed that the indigenization requirement was inconsistent with GATT Article III(4), which provides:

The products of the territory of any contracting party imported into the territory of any other contracting party shall be accorded treatment no less favorable than that accorded to like products of national origin in respect of all laws, regulations and requirements affecting their internal sale, offering for sale, purchase, transportation, distribution or use.

To evaluate the indigenization measure against this standard, the panel believed that four issues must be addressed: "whether (1) imported products and domestic products are like products; (2) the measures constitute a "law, regulation or requirement"; (3) they affect the internal sale, offering for sale, purchase, transportation, distribution or use; and (4) imported products are accorded less favourable treatment than the treatment accorded to like domestic products."

Regarding the first issue, the dispute involved imported and domestic parts and components of automobiles, distinguished only by their origin. The panel saw no basis for treating imported and domestic products as other than "like," and India did not dispute the point. ${ }^{10}$

Regarding the second issue, both the European Communities and the United States argued that the indigenization requirement in PN60 and embodied in the MOUs was a "requirement" under Article III(4). Companies were not compelled to subject themselves to it, but they had to do so if they wished to obtain a government benefit (an import license). Citing GATT precedent, the panel accepted the proposition that the term "requirement" includes "those which an enterprise voluntarily accepts in order to obtain an advantage from the government." 11

But India argued that once the import licensing regime was abolished, any "requirement" ceased to exist - no longer would any company have to agree to the indigenization requirement to obtain an import license. The panel gave a twofold response. First, its terms of reference required it to assess the legality of the measures in place at the time the panel was constituted, and on that date the licensing regime was still in place. Second, even after the

\footnotetext{
9 Panel Rep. 7.172.

10 Panel Rep. 7.174.

11 Panel Rep. 7.183.
} 
licensing regime was abolished, the MOUs remained enforceable as private contracts with the government and could be expected to affect commercial behavior regardless of the government's enforcement policy. ${ }^{12}$

India's final argument was that even if the MOUs remained enforceable, private contracts with the government were analogous to "discretionary" legislation. It pointed to the distinction under the old GATT system between mandatory legislation, which left administering officials with no discretion to avoid violations if certain circumstances arose, and discretionary legislation, which might result in a violation but always be administered in a way that avoided violations. Only the former type of legislation could be challenged "on its face" in the GATT system; the latter could be challenged only if was applied in a manner that resulted in a violation. To this line of argument, the panel suggested that binding contractual obligations might be expected to affect companies' behavior, even if the government did not actively enforce them. ${ }^{13}$ Further, India had apparently conceded that it had not released companies from their MOUs and had no plans to do so in the future. ${ }^{14}$

The third and fourth issues under Article III(4) were easily resolved. The indigenization requirement "affected" internal sale, and accorded imported products less favorable treatment, because it modified conditions of competition between imported and domestic like products and encouraged companies to buy domestic over imported products. ${ }^{15}$

The United States also argued that the indigenization requirement was inconsistent with Article XI(1), and both complainants challenged the requirement under TRIMs. Having ruled that it was inconsistent with Article III(4), however, the panel declined to examine its consistency with Article XI or with TRIMs.

\subsubsection{The trade balancing requirement Both the European} Communities and the United States argued that aspects of the trade balancing requirement were inconsistent with Articles III and XI of GATT 1994, although their positions differed in certain details. The panel saw greater common ground in their discussion of Article XI, and decided to address issues under Article XI first.

12 Panel Rep. 7.190-7.193.
13 Panel Rep. 8.42-8.44.
14 Panel Rep. 8.46.
${ }_{15}$ Panel Rep. 7.196-7.202. 
Article XI(1) provides:

No prohibition or restriction other than duties, taxes or other charges, whether made effective through quotas, import or export licenses or other measures, shall be instituted or maintained by any contracting party on the importation of any product of the territory of any other contracting party or on the exportation or sale for export of any product destined for the territory of any other contracting party.

The trade balancing requirement was not in itself a "quota, import or export license," and so the initial question was whether it is among the 'other measures' covered by Article XI(1). The panel had little difficulty concluding that it was. It reasoned that the balancing requirements, embedded in the MOUs, resulted directly from the legislative enactment PN60 and thus represented "measures" by the Indian government.

The next question was whether the "measure" amounted to a "restriction... on the importation" of goods. India contended that the measure did not relate directly to the entry of goods into Indian customs territory, and thus was not a "restriction on importation." The panel disagreed, relying on the plain meaning of "restriction." It simply noted that the balancing requirement prohibited imports in excess of stipulated amounts determined by each company's exports. It was further "comforted" by the following language to be found in the Illustrative List of TRIMs:

TRIMS that are inconsistent with the obligation of general elimination of quantitative restrictions provided for in paragraph 1 of Article XI of GATT 1994 include those which are mandatory or enforceable under domestic law or under administrative rulings, or compliance with which is necessary to obtain an advantage, and which restrict:

(a) the importation by an enterprise of products used in or related to its local production, generally or to an amount related to the volume or value of local production that it exports. ${ }^{16}$

The trade balancing requirement thus came within Article XI(1), and violates GATT 1994 in the absence of an effective defense. India claimed a balance of payments defense as in the earlier proceeding, but presented no evidence on the matter. The panel ruled, following prior decisions, that India had the burden of proof when asserting an affirmative defense under Article XVIII:B, and that its failure to come forward with evidence meant that its defense necessarily failed.

${ }^{16}$ Panel Rep. 7.279. 
Having found an inconsistency with Article XI, the panel again appealed to judicial economy to avoid a full discussion of the trade balancing measure in relation to Article III and TRIMs. The panel did address one specific feature of the trade balancing requirement in relation to Article III(4). It noted that any company subject to an MOU buying a previously imported $\mathrm{CKD}$ or SKD kit in the Indian domestic market would have that purchase counted as an "import" for purposes of the trade balancing requirement. Thus, previously imported kits were disadvantaged on domestic resale relative to domestically produced like products. The panel was of the view that, whatever the proper boundary between the measures covered by Article III and XI in general, a measure disadvantaging imported goods on domestic resale was a potential violation of Article III(4). Proceeding through the four issues laid out above in the discussion of the indigenization requirement in relation to Article III(4), the panel again found that the trade balancing requirement incorporated a "requirement affecting internal sale" that afforded less favorable treatment to imported like products. ${ }^{17}$

\subsection{The Appellate Body decision}

As noted in the introduction, India ultimately withdrew its notice of appeal and rescinded PN60 without further proceedings. Accordingly, the Appellate Body did not consider the substantive issues in the case.

\section{Critical analysis}

\subsection{Legal commentary}

The automotive dispute was largely a "mopping up" operation aimed at eliminating some remaining vestiges of the import licensing regime that had been found to violate WTO law in India - Quantitative Restrictions. During that regime, the indigenization and trade balancing requirements in the automotive sector had been made effective through contracts (MOUs) with the government that companies executed to obtain import licenses. The contracts remained in force even after the licensing scheme was abolished, and the government gave no indication of an intention to release companies from them (indeed, it indicated to the contrary before the dispute panel).

17 Panel Rep. 7.295-7.309. 
The indigenization requirement was a classic "local content" requirement, a paradigm example of the sort of measure that was the target of the TRIMs agreement and that had been held to violate Article III(4) of GATT 1994 in the past. ${ }^{18}$ The trade balancing requirement, in so far as it limited the value of goods imported by a company to the value of its exports, was likewise a clear target of TRIMs and was well understood to violate Article XI of GATT 1994. ${ }^{19}$ Finally, the aspect of the trade balancing requirement that limited the capacity of companies to purchase products imported by others, and thus affected their domestic resale, was also a target of TRIMs and a clear violation of GATT Article III(4). ${ }^{20}$ India's balance of payments defense for such measures had been rejected previously, and India's reassertion of that defense in this case was at best half-hearted.

The case touches on a few broader issues, but in the end does not say much about them. India's peculiar invocation of res judicata as to issues that it had lost in India - Quantitative Restrictions raises a general question about the place of doctrines like res judicata and collateral estoppel in the WTO system. The panel seemed willing to accept that it was inappropriate to relitigate identical issues between the same parties that had been resolved in prior disputes, but avoided any definitive statement on the matter simply by noting that the issues raised by PN60 and the MOUs were new and had not been previously considered.

The differences in the positions of the United States and Europe as to the applicability of GATT Articles III and XI to the various measures highlights another issue that has perplexed WTO/GATT scholars through the years, namely, the precise boundary between the measures covered by Article III and the measures covered by Article XI. The same issue confronted an old GATT panel faced with a challenge to the Canadian Foreign Investment Review Act, which stated in the course of its opinion:

The Panel shares the view of Canada that the General Agreement distinguishes between measures affecting the 'importation' of products, which are regulated in Article XI:1, and those affecting 'imported products', which are dealt with in Article III. If Article XI: 1 were interpreted broadly to cover also internal requirements, Article III would be partly superfluous. ${ }^{21}$

${ }^{18}$ See TRIMs Annex, Illustrative List 1(a).

19 See TRIMs Annex, Illustrative List 2(a).

${ }^{20}$ See TRIMs Annex, Illustrative List 1(b).

${ }^{21}$ GATT Panel Report, L/5504, adopted on 7 February 1987, 5.14. 
The potentially elusive distinction between measures affecting "importation" and those affecting "imported products" is to a considerable degree unimportant. Complaining nations will usually care little whether a measure is found illegal under Article III or Article XI as long as it is found illegal under one of them, and there is no obstacle under WTO law to alternative pleading. But whatever its importance, the panel's treatment of the issues here sheds no new light on the distinction. The panel does not broach the general question of how to draw the line, but instead maneuvers its order of analysis to follow the classification scheme in the TRIMs Annex: ${ }^{22}$ Based on the illustrative list in the Annex, the indigenization requirement and the part of the trade balancing requirement that applies to previously imported goods are measures affecting "imported products" subject to Article III. But the trade balancing requirement affects "importation" when it restricts what a company may import directly. It will be recalled that the panel analyzed the indigenization requirement under Article III and invoked judicial economy to avoid considering it under Article XI. It did the opposite with the trade balancing requirement, save for the part of it that applied to previously imported goods which was analyzed under Article III. The panel thus applied the pertinent GATT articles as TRIMs suggests they should be without actually ruling on the dividing line between them.

One of the more interesting issues in the case relates to the distinction in old GATT jurisprudence between "mandatory" and "discretionary" legislation. The continued vitality of that distinction in WTO law remains an open question, to be sure, and one unappealed WTO panel decision concerning Section 301 of the U.S. Trade Act of 1974 questions its utility. ${ }^{23}$ Nonetheless, WTO Members continue to raise the distinction in various contexts, and it surfaced in an interesting way in the automotive dispute. India argued that the measures contained in the MOUs were in the nature of contractual provisions that the government could elect not to enforce. As such, they were analogous to "discretionary legislation" - legislation that might be administered in such a way as to violate WTO law, but that affords sufficient discretion to administrators to avoid any violations. Under GATT jurisprudence, such legislation could not be challenged "on its face," but only if it resulted in a violation

${ }^{22}$ See text accompanying notes $18-20$ supra.

23 See Panel Report in United States - Sections 301-310 of the Trade Act of 1974, WT/DS152/R, adopted January 27, 2000, 7.51-7.53. 
as applied. Thus, India reasoned, the measures embodied in the MOUs could be challenged only if India took some steps to enforce them.

As noted, the panel rejected this line of reasoning by noting that India had not stated an intention to release companies from their MOUs, and that a mere possibility of enforcement action might encourage companies to follow their MOU commitments. Both observations are no doubt correct, but they may prove too much. It is perhaps often the case that legislation deemed "discretionary" under the old GATT system has some chilling effect at odds with GATT obligations because of the possibility of enforcement in a way that violates GATT. Only when a government unequivocally and credibly commits itself to administer the legislation in a way that complies with GATT might any such "chilling effect" be avoided. Thus, the analogy between the MOUs and discretionary legislation is stronger than the panel allowed. Its resolution of the matter perhaps hints at a new principle that also resonates with the panel decision in United States - Section 301: It is not enough that a measure affords administrative "discretion" to avoid violations of WTO law. To avoid challenges to such a measure on its face, a country must also provide credible assurances that administrative discretion will in fact be exercised in a way that averts any violations.

\subsection{Economic commentary}

We turn now to consider the economic aspects of local content requirements. A common form of a local content requirement specifies that a certain physical proportion of domestic inputs be embodied in the final good. We focus here on the economic implications of such local content requirements under different market structures.

A local content requirement is a protectionist instrument that is logically distinct from both import tariffs and import quotas. Unlike tariffs and quota licenses, a local content requirement does not generate government revenue. Such a requirement does, however, create a wedge between the prices of domestic and foreign inputs. When an effective local content requirement is in place, a foreign final good producer with a domestic plant is induced to increase the demand for domestic inputs, thereby raising the price of the domestic input relative to that of the foreign input. The domestic government then balances the consequent benefit to domestic input suppliers against the associated cost to domestic consumers, where the latter cost is experienced if the higher domestic input price leads to a higher domestic price for the final good. 
The local content requirement also generates an international externality, if it reduces the profits of the foreign final good manufacturers and/or foreign input suppliers. When setting its preferred unilateral policy, the domestic government does not internalize such an effect. Thus, when a local content rule changes prices in such a way as to create an international externality, a role may arise for an international trade agreement that imposes restrictions upon local content requirements.

Using three models, we explore here the domestic effects of a local content requirement and also the circumstances under which such a requirement generates an international externality. The models share a common foundation. In each case, a final good (autos) is produced, where each unit of the final good requires one unit of the input (kits). The final good manufacturers are foreign (US). The input is supplied by a competitive market in the foreign country (US) and also by a competitive market in the domestic country (India). The domestic and foreign inputs are perfect substitutes, and the final good requires no other input. The models differ in terms of the market power that the foreign final good manufacturers and the domestic government are assumed to possess.

Model 1: competitive final good market, small domestic country We consider first a setting in which the final good is produced by a competitive industry comprised (for simplicity) of foreign firms. Final good manufacturers then earn zero profit, and so the domestic government is unable to use a local content requirement as a means to extract profit from foreign manufacturers. Furthermore, we assume that the domestic country is small, in the sense that the reduction in demand for foreign inputs caused by the local content requirement does not depress the (world) price of foreign inputs. This means that the profits of foreign input suppliers are also unaffected by the local content requirement. Our first setting is thus a benchmark case in which no international externality arises. ${ }^{24}$

To examine the domestic consequences of a local content requirement, we introduce the following notation. Let $\mathrm{Q}$ and $\mathrm{P}$ denote the output and price of the final good in the domestic market, respectively. This output is produced by a competitive final good market according to the technology $\mathrm{Q}=\mathrm{X}+\mathrm{X}^{*}$, where $\mathrm{X}$ is the quantity of input purchased from domestic

${ }^{24}$ For further discussion of related models, see Corden (1971), Grossman (1981) and Vousden (1990, Chapter 2). 
suppliers and $\mathrm{X}^{*}$ is the quantity of input purchased from foreign suppliers. The local content requirement specifies that a fraction $\mathrm{k}$ of inputs be purchased from domestic suppliers; thus, when this requirement is (exactly) met, $\mathrm{X}=\mathrm{k}\left(\mathrm{X}+\mathrm{X}^{*}\right)=\mathrm{kQ}$. Let $\mathrm{r}$ and $\mathrm{r}^{*}$ denote the respective prices of the domestic and foreign inputs. In the present model, $\mathrm{r}^{*}$ is fixed and independent of any local content requirement, but the local content requirement may affect $r$ and thus the average price of the input, $r_{a}=k r+(1-k) r^{*}$. Since the final good industry is competitive and uses only a single input, the price of the final good is equal to the average price of the input: $\mathrm{P}=\mathrm{r}_{\mathrm{a}}$

As illustrated in Figure 1, the domestic supply of the input is described by an upward-sloping supply function, $X(r)$, while the supply of the foreign input is perfectly elastic at the price $r^{*}$. We assume that the domestic supply function initially lies below the foreign supply function (i.e., the first unit of domestic supply is offered at a price below $\mathrm{r}^{*}$ ) and then crosses the foreign supply curve at some quantity $\mathrm{X}_{\mathrm{f}}$. The demand for the final good is represented by the downward-sloping demand function, $\mathrm{D}(\mathrm{P})$. Under free trade, all inputs trade at the price $\mathrm{r}^{*}$ and the total quantity of inputs that is demanded (and thus the quantity of the final good that is produced) is given by $\mathrm{Q}_{\mathrm{f}}=\mathrm{D}\left(\mathrm{r}^{*}\right)$. Accordingly, $\mathrm{X}_{\mathrm{f}}$ units of the domestic input are employed, and $\mathrm{X}_{\mathrm{f}}^{*}=\mathrm{Q}_{\mathrm{f}}-\mathrm{X}_{\mathrm{f}}$ units of the foreign input are employed. Let $\mathrm{k}_{\mathrm{f}}=\mathrm{X}_{\mathrm{f}} / \mathrm{Q}_{\mathrm{f}}$ denote the fraction of the domestic input used under free trade.

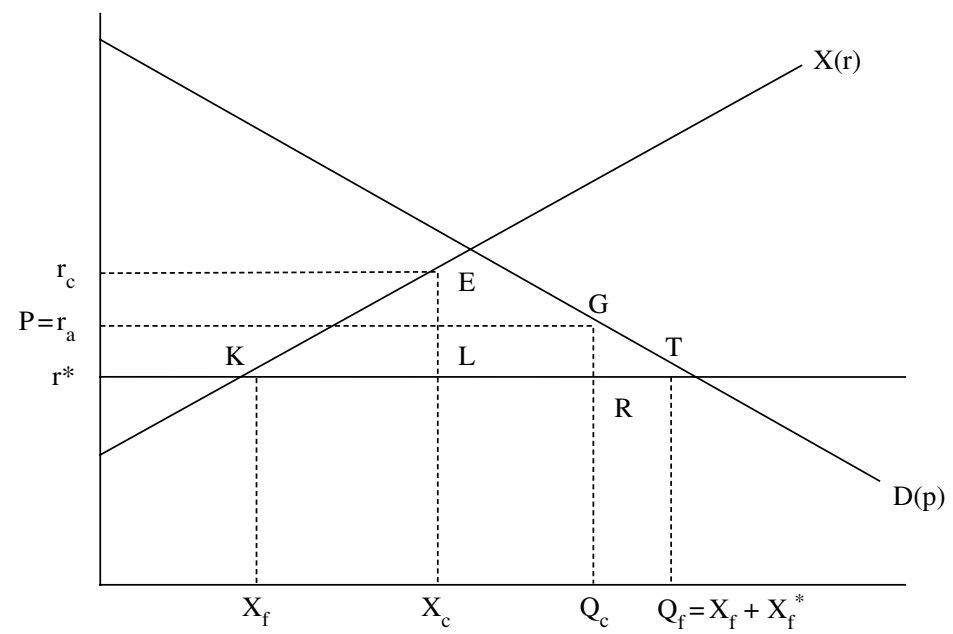

Figure 1. 
Consider now the imposition of a local content requirement under which $\mathrm{k}>\mathrm{k}_{\mathrm{f}}$. Such a policy must elicit a greater supply of the domestic input and so requires an increase in the domestic input price, $r$. The equilibrium outcome is illustrated by point $\mathrm{E}$. At this point, the price of the domestic input is $r_{c}>r^{*}$ and the quantity of the domestic input used is $\mathrm{X}_{\mathrm{c}}>\mathrm{X}_{\mathrm{f}}$. Thus, the domestic input is now used at a higher volume and commands a higher price. The local content requirement also induces an increase in the average input price, with $r_{a}=k_{c}+(1-k) r^{*}>r^{*}$. This means that the total quantity of input that is demanded (and thus the quantity of the final good that is produced) is reduced by the local content requirement: $\mathrm{Q}_{\mathrm{c}}=\mathrm{D}\left(\mathrm{r}_{\mathrm{a}}\right)<\mathrm{D}\left(\mathrm{r}^{*}\right)=\mathrm{Q}_{\mathrm{f}}$.

What are the domestic welfare consequences of the local content requirement? To answer this question, it is easiest to imagine that the first $X_{c}$ units of final good output are sold at the price $r_{c}$ while the next $Q_{c}-X_{c}$ units are sold at the price $r^{*}$. (The average price is then $r_{a}$.) We begin with the first $X_{c}$ units. The area ${ }^{*} r_{c}$ EL represents consumer surplus that is enjoyed under free trade and lost under the local content requirement. Some of this surplus is transferred to domestic input suppliers, who now enjoy additional producer surplus corresponding to the area $\mathrm{r}^{*} \mathrm{r}_{\mathrm{c}} \mathrm{EK}$. The remaining area of lost consumer surplus, KLE, is deadweight loss that is attributable to a production inefficiency that occurs when efficient foreign supply of inputs is displaced by domestic input supply. Now consider the next $Q_{c}-X_{c}$ units that are sold at the price $r^{*}$. For these units, the local content requirement has no effect on the final good price or welfare. Finally, we note that the local content requirement results in a reduction in the total output of the final good (from $Q_{f}$ to $Q_{c}$ ). The corresponding area, RTG, represents a second source of deadweight loss associated with the local content requirement.

In total, then, the local content requirement reduces domestic national income, due to the creation of deadweight loss as captured by the areas KLE and RTG. Of course, if the domestic government has political objectives such that it values the benefits to input suppliers (i.e., the area $r^{*} r_{c} E K$ ) more heavily than the costs to consumers (i.e. the areas $r^{*} r_{c}$ EL and RGT), then a local content requirement may be attractive. ${ }^{25}$

In this model, all of the costs and benefits of the local content requirement reside within the domestic economy. Since the foreign final good

${ }^{25}$ A local content requirement may also be attractive to the domestic government if the domestic input industry is subject to learning by doing. The analysis of this effect, however, requires a dynamic model. 


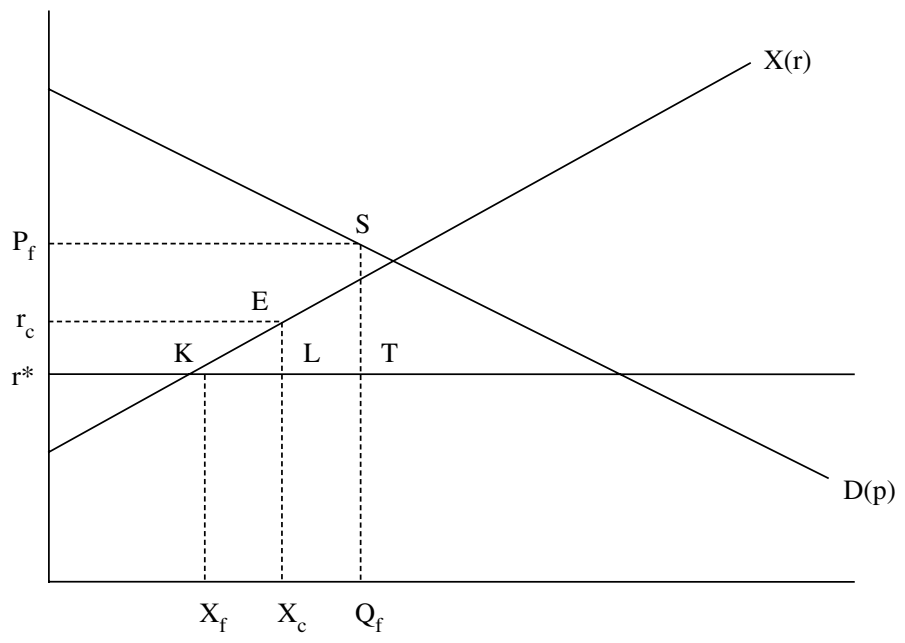

Figure 2.

manufacturers earn zero profit and the price at which foreign inputs sell on world markets is fixed, the local content requirement has no international externality. When the assumptions of this model hold, no obvious role for the WTO arises, since the local content requirement is a domestic policy that does not affect the welfare of any other Member government. $^{26}$

Model 2: monopoly final good market, small domestic country Maintaining the assumption that the domestic country is small, we now posit that the final good is produced by a foreign monopoly. The wrinkle here is that the foreign final good industry generates profit, and so a local content requirement may be entertained as a means through which to extract profit from the foreign final good monopoly and shift it to the domestic input suppliers. ${ }^{27}$ An international externality is thus suggested.

As above, we consider a local content requirement that requires the monopolist to use a greater fraction of domestic input than it would

26 Thus, when the assumptions of this model apply, if the foreign government challenges the domestic local content policy, then the domestic government has a solid economic basis from which to rebut a charge of nullification or impairment. We note, however, that these assumptions represent an instructive but extreme benchmark, in which all market power is absent.

27 Brander and Spencer (1981) explore a related model, in which tariffs may be used to extract profit from a foreign monopolist. 
under free trade. An important issue concerns the manner in which the monopolist adjusts its output in response to this requirement. To illustrate the issues involved, we first imagine that the foreign monopolist does not change its output following the imposition of the local content policy. The local content requirement then amounts to a transfer from the final good monopolist to the domestic input supply industry, since the monopolist must offer a higher domestic input price in order to elicit the increased domestic input supply. This strategic policy is attractive to the domestic government, even when the government has no political objective and simply maximizes national income, but the policy lowers world welfare, since it creates a productive inefficiency: on the margin, foreign input suppliers are replaced by less efficient domestic input suppliers.

These effects are illustrated in Figure 2. Under free trade, the foreign monopolist sets the price $\mathrm{P}_{\mathrm{f}}$ and produces the output $\mathrm{Q}_{\mathrm{f}}$, and $\mathrm{X}_{\mathrm{f}}$ units of the inputs are domestically supplied. The profit earned by the foreign monopolist is given by the area $\mathrm{r}^{*} \mathrm{P}_{\mathrm{f}} \mathrm{ST}$. When the local content requirement is imposed, a greater proportion of the (fixed) output must embody the domestic input. Thus, the domestic input price rises to $r_{c}>r^{*}$, and the use of the domestic input rises to $X_{c}>X_{f}$. The area $r^{*} r_{c} E K$ then represents profit that is extracted from the monopolist and shifted to the domestic input supply industry. The triangle KEL is lost profit that becomes deadweight loss. Thus, if the output of the foreign monopoly is held fixed, a local content policy is attractive to the domestic government as a means of shifting foreign monopoly profit to the domestic input supply industry. Such a policy imposes a negative international externality on the foreign monopolist (and thus the foreign government) and results in a loss in world welfare.

But of course the foreign monopolist is unlikely to keep its final good output constant. At the free-trade quantity, the local content policy induces a higher input price on all units of the domestic input without changing the input price of any units of the foreign input. The local content policy thus raises the costs of production, and as a consequence the foreign monopolist will respond by lowering its output. ${ }^{28}$ In turn, this

28 This raises the possibility that the local content rule might result in less overall use of the domestic input. While this possibility cannot be dismissed, plausible conditions can be identified under which a small local content requirement (i.e., a policy that requires that a slightly larger fraction of the domestic input be used than would be used under free trade) results in an overall increase in the use of the domestic input, and we will proceed on that assumption. For a general analysis and further discussion, see Grossman (1981). 
means that a local content requirement induces a loss in consumer surplus for the domestic country. Accordingly, the domestic government must balance the benefit of profit shifting (from the foreign monopolist to the domestic input industry) against the cost of a decline in consumer surplus in the final good market. As a general matter, it is unclear whether a national-income maximizing government would seek to impose a local content policy. It is clear, though, that such a policy is attractive to the domestic government, if this government has political objectives such that it values sufficiently the profit of input suppliers relative to the surplus of final good consumers.

In this second model, not all of the costs and benefits of the local content requirement reside within the domestic country. If the domestic government chooses to impose a local content requirement (for whatever reason), then the welfare of the foreign government is reduced, since its monopolist suffers a reduction in profit. Thus, when market power in the final good industry exists, a local content policy is associated with an international externality, and a rationale for WTO rules that prohibit local content policies is provided.

Model 3: monopoly final good market, large domestic country In the previous model, we introduce market power with the assumption that the final good is produced by a foreign monopoly. Our next step is to add market power over the input market as well, with the assumption that the domestic country is large, in the sense that a reduction in the demand of the foreign input by the foreign monopolist when serving the domestic market results in a decline in the (world) price of the foreign input. In this third model, a local content requirement may extract profit from the foreign monopolist and affect as well the profit of foreign input suppliers.

The novel assumption here is that the foreign monopolist faces foreign and domestic input supply functions that are upward-sloping. We assume further the input supply functions are symmetric. Under free trade, an efficient foreign monopolist then uses the same volume of domestic and foreign inputs, and the input prices are thus equated in the two markets. To assess the impact of a local content requirement, we again first imagine that the foreign monopolist does not change its output in response to the local content policy. As before, at a given quantity of output, an effective local content requirement forces the monopolist to use more of the domestic input, and the supply of this input is forthcoming only when the domestic input price rises. The local content rule again extracts profit from the foreign monopolist and shifts it to the domestic input industry. 
We next consider the possibility that the foreign monopolist adjusts its quantity of output following the imposition of the local content requirement. At the free-trade quantity, the local content policy induces a higher input price on all units of the domestic input but now also results in a reduction in the foreign input price on all units of the foreign input. The latter effect arises only in the third model, and reflects the fact that the monopolist's reduced demand for foreign inputs causes a decline in the price of the foreign input. Now, if the local content policy is small (i.e., if it calls for only a slight increase in the use of the domestic input, when the monopolist produces the free-trade output level), then the policy has essentially no effect on the monopolist's costs: as before, the monopolist pays a slightly higher input price on all units of the domestic input, but now it also pays a slightly lower input price on all units of the foreign input; furthermore, under our symmetry assumption, it uses approximately the same amount of domestic and foreign inputs, when the local content policy is small. This means that the monopoly output is essentially unchanged after the imposition of a small local content policy. Such a policy thus generates a profit-shifting advantage for the domestic country without causing a loss in consumer surplus. Hence, a small local content policy is sure to be attractive to the domestic government, even if the domestic government maximizes national income.

The case for WTO restrictions against local content requirements is now quite clear. The domestic government has an unambiguous incentive to impose a small local content policy, but such a policy is unambiguously bad for the foreign monopolist and thus the foreign government, and indeed lowers global welfare overall. In other words, the rationale for WTO involvement with respect to local content policies is now the same as the rationale for WTO involvement with respect to tariffs by large countries. In each case, a small amount of the policy is unambiguously beneficial to the party that uses the policy, and unambiguously harmful to the trading partner and world welfare, with all of these implications holding even when benefits are measured in national-income terms.

\section{Summary}

Our analysis here reveals that local content requirements may be attractive as a unilateral policy in some circumstances. When markets are competitive and the domestic country is small, such policies may cause a redistribution of surplus from domestic consumers to the domestic input supply industry, with no associated international externality. The 
situation changes, however, when market power is present. If a foreign monopolist supplies the final good, then a local content policy may extract profit from the foreign monopolist and redistribute this surplus to the domestic input supply industry. Such a policy is more attractive to the domestic government if the foreign monopolist does not respond with a significant reduction in output. This is in turn more likely when the domestic country is large, in the sense that the associated reduction in demand for the foreign input results in a decline in the price of the foreign input. Accordingly, we conclude the local content policies may be attractive to the domestic government and harmful to the trading partner when market power is present. WTO rules that restrict the application of local content policies then rest on a firm economic foundation.

While the models developed above abstract from a number of features that characterize the market for automobile manufacturing in India, we believe that they nevertheless provide useful lessons. In particular, we speculate that US and European automobile manufacturers in India possess some market power. Our analysis thus suggests that local content requirements may be designed to shift the associated profit from foreign automobile manufacturers to domestic input suppliers. Consequently, our analysis provides support for WTO prohibitions against such requirements as they arise within the automotive sector in India.

We conclude with some brief remarks concerning the economics of the trade balancing requirement. Like a local content policy, a trade balancing requirement can limit the imports of the foreign input and thereby increase the price of the domestic input relative to that of the foreign input. When some market power is present, a trade balancing requirement may thus shift profit from the foreign final good industry to the domestic input industry. An international externality is then created and a role for WTO involvement is thus implied. A novel aspect of the trade balancing requirement, however, is that the foreign final good industry may increase exports in order to loosen the restrictions on its imports. The possibility of an induced expansion in exports suggests a more complex pattern of international externalities across trading partners.

\section{References}

Brander, James and Barbara Spencer (1981), "Tariffs and the Extraction of Foreign Monopoly Rents under Potential Entry," Canadian Journal of Economics, vol. 14, 371-389. 
Corden, W. M. (1971), The Theory of Protection, Oxford: Oxford University Press.

Grossman, Gene M. (1981), "The Theory of Domestic Content Protection and Content Preference," The Quarterly Journal of Economics, Vol. 96, No. 4, November, 583-603.

Vousden, Neil (1990), The Economics of Trade Protection, Cambridge: Cambridge University Press. 